https://doi.org/10.17048/AM.2020.262

\title{
Kiss Veronika
}

Eszterházy Károly Egyetem, Sporttudományi Intézet

veronikiss@gmail.com

\section{IKT-eszközökkel támogatott egészségre nevelés az általános iskolában}

\section{Absztrakt}

Személyi edzőként a felnőttekkel való foglalkozásom során fogalmazódott meg bennem a kérdés, hogyan tudnám már az általános iskolás gyerekeket megtanítani arra, hogy egészség- és testtudatos felnőtté váljanak.

Úgy gondolom, hogy mobilapplikációval kiegészítve az egészségre nevelés folyamatát könnyebben átadhatók és gyakorlatba ültethetők az információk a 6-14 éves gyerekek számára. Tekintettel az online oktatás során szerzett tapasztalatokra és néhány korábbi kutatási eredményre (Révész, 2019) a digitális eszközök bevonása a testnevelés órák esetén is növeli a tanítás-tanulás hatékonyságát.

IKT eszközök segítségével hatékonyan tanítható, milyen gyakorlatokat hogyan végezzenek (Varga, 2018.) és - ami a jelen megoldások hiányossága -, hogy azokat miért tegyék pl. zsírégetés, ízületi mozgékonyság, testoptimalizáció, izomtónus fokozás, izomtónus egyensúly. Emellett mozgástevékenységük mérhetővé is válik az eszközök által, pl. pulzus, ami a differenciált oktatás megvalósításában is jelentős szerepet játszhat (Nagy et al, 2016.). Mobilapplikációkban egyénre szabott edzésterveket kaphatnának, amelyekben visszatekinthetővé válna mozgástevékenységük és játékos motivációt is kapnának úgy, hogy például egészséges ételeket gyűjtenek bizonyos gyakorlatok elvégzésével.

Kutatásom célja bizonyítani, hogy lehetséges IKT eszközökkel segítve megtanítani az általános iskolában az egészségtudatos, testtudatos felnőtté válást úgy, hogy elméleti háttértudást és gyakorlati feladatokat is biztosítok digitális applikációkon keresztül.

Kutatásom egyik kiinduló hipotézise, hogy a köznevelési tananyagban nincs elegendő tudásanyag ahhoz, hogy a gyerekek képesek legyenek annak alapján egészséges életmódot folytatni a mindennapokban és mozgással fenntartani egészségüket, karban tartani testüket adottságaikhoz illeszkedő módon.

Jelen elődásomban feltérképezem a közoktatási tananyagokban elérhető kapcsolódó témaköröket, a Nemzeti Köznevelési Portálon elérhető online tananyagok tartalmának elemzésével, beazonosítva a hiányzó szakmai tartalmi területeket. 
Kulcsszavak: IKT-eszközök, mobilapplikáció, testnevelés, NAT

\section{Bevezetés, motiváció}

Kutatásomat az indította el, hogy személyi edzőként olyan felnőtt emberek keresnek meg, akiknek az életmódbeli-, és táplálkozási szokásaikból adódóan súlyfelesleg, és/vagy belsőszervi elváltozás, vagy mozgásszervi elváltozás a problémájuk. Ezeknek okai lehetnek részben:

- az általános iskolai rossz testnevelés,

- az egészségmegőrzés, prevenció hiánya,

- az egészségfejlesztés hiánya,

- biológia tantárgyi tudásuk hiányos, vagy nincs megfelelően átültetve az elmélet a gyakorlatba.

A tantárgyi tudás kapcsán felmerülő kérdések:

- A tanórákon elhangzó információ hiányos?

- Az információ minősége, mennyisége nem megfelelő vagy hiányos?

- Az információátadás módszere nem megfelelő?

Testnevelő tanárként az általános iskolában azt tapasztalom, hogy a diákoknak gyenge az izomzatuk, nem bírják el a saját testsúlyukat, lassúak, merev a mozgatórendszerük, nem megfelelően táplálkoznak. Annak érdekében, hogy problémáikon a testedzésekkel segítsek, a tananyagot is rendszerint átdolgozom, az órákon és a felnőttekkel folytatott munkám során szerzett tapasztalataim alapján.

Igyekszem minél inkább felhívni a gyerekek figyelmét a testük rendszeres átmozgatására, edzésére, a jó testtartásra és a helyes táplálkozásra. Azt tartom szem előtt, amikor tanítom őket, hogy átadjam azokat az alapvető ismereteket, amelyek feltétlenül szükségesek ahhoz, hogy felnőttként egészségesek és fittek legyenek majd, és olyan tudásra, sőt motivációra tegyenek szert, amely biztosítja számukra, hogy azok is maradjanak egész életük során.

\section{Háttérirodalom, kutatási kérdések}

2020. márciusban az iskoláknak online oktatásra kellett átállniuk a COVID-19 vírus miatt, ami a testneveléstanítás módszerét számomra villámgyorsan felborította. A meglévő gyakorlati órákat felváltotta az online oktatás, amely rengeteg kérdést vetett fel és egyben új lehetőségeket is adott. Felértékelődött a tanárok és a diákok számára otthon elérhető IKT eszközök szerepe és az internet jelentősége, hiszen ezek biztosították a tanítás-tanulás új platformját, valamint a tanár-diák kommunikációjának egyetlen lehetséges útját. 
Az eszközök motiváló hatásait már több kutatás is kimutatta (Lengyelné, 2009), azonban az IKT eszközök integrálása az oktatási folyamatokba a testnevelés tantárgy kapcsán is egyre inkább előtérbe kerül. Fontossá vált az is, hogy a testnevelő tanárok megfelelő IKT-kompetenciával rendelkezzenek és vizsgálatra kerüljenek az IKT-használati szokásaik valamint a digitális eszközökhöz való viszonyulásuk (Varga, 2018), (Racsko - Kis-Tóth, 2019). Néhány korábbi kutatási eredmény egyértelműen alátámasztja azt, hogy a digitális eszközök bevonása a testnevelés órák esetén is növeli a tanítás-tanulás hatékonyságát, mindemellett az iskolákban a testnevelés órákkal kapcsolatosan az infrastruktúrafejlesztési törekvéseknél nem kap nagy szerepet az IKT-eszközpark fejlesztése (Révész, 2019).

Pedig IKT eszközök segítségével a diákok mozgástevékenysége mérhetővé is válik, pl. pulzus, ami a differenciált oktatás megvalósításában jelentős szerepet játszhat (Nagy et al, 2016). Magam is úgy gondolom, hogy a digitális eszközök bevonása a mozgásos tevékenységekbe nagy segítségre lehetnek az egészségre nevelés során illetve nagy szerepük lehet a mozgásra való motiválás terén.

Újra felvetődtek bennem az online oktatás során is azok a kérdések, amelyeket a bevezetőben már feltettem. Először az általános iskolában átadható tananyagtartalom áttekintését tettem meg, megvizsgáltam, hogy megfelelő alapot képez-e az egészséges életmódra neveléshez.

\section{A NAT valamint az 5.-es és 6.-os tankönyv tartalma}

A kutatási probléma megvizsgálásának első lépéseként a Nemzeti alaptanterv elemzését végeztem el. A dokumentumelemzés (Lengyelné, 2014) folyamata során vizsgáltam, hogy megfelelő információ, kompetencia terület áll-e rendelkezésre ahhoz, hogy a célt felnőttként elérjük, azaz a gyermekekből egészséges, fitt felnőtt emberek váljanak.

Az alábbiakban a NAT-ban szereplő, egészséges életmódra neveléssel kapcsolatos tartalmakat mutatom be.

A testnevelés és egészségfejlesztés az egyik legösszetettebb tanulási terület, meglehetősen komplex célkitúzéssel.

A tanulók:

- testi,

- lelki,

- értelmi,

- érzelmi és

- szociális fejlődését kell szolgálnia, biztosítania. 
A koordinációs képesség fejlesztésének szenzitív szakasza erre az életkorra tehető. A mozgásszükségletet úgy kell kialakítani, hogy a motoros képességek fejlesztése, a mozgásmúveltség kialakítása, és fejlesztése, a természetes mozgások megszilárdítása nagyon hangsúlyosan jelenjen meg, előtérbe helyezve a játékos cselekvéstanulást.

Az izomérzékelés, ritmus- és reakcióképesség, a térbeli tájékozódó képesség, és az egyensúlyozó képesség fejlesztése - mindezt az információt megtaláltam a NAT-ban.

A NAT-ban szerepelnek az alap- vagy természetes mozgások is, amelyek a következők:

- futás,

- ugrás,

- dobás,

- támaszkodás,

- függés,

- egyensúlyozás,

- úszás.

A testnevelés és egészségfejlesztés a személyiségfejlődésnek más területeire is hatást gyakorol. Különböző mozgásformák elsajátítása jelentős befolyással bír a kognitív fejlődésre.

\section{MOZGÁSOS CSELEKVÉS = CÉLIRÁNYOS KOMPLEX KOGNITÍV MOTOROS TEVÉKENYSÉG}

A prevenció, és életvitel tanulási terület tartalmazza:

- a keringési rendszert,

- a légzőrendszert,

- a mozgató rendszert fejlesztő alapvető mozgásformákat.

Rendszeres testmozgást ír elő, javasol.

Az egészséges testi fejlődés, egészségfejlesztés rész tartalmazza:

- a sporttáplálkozás alapelveit,

- az egészséges és egészségtelen tápanyagforrások különbözőségeit.

Áttekintettem a Nemzeti Köznevelés Portálon ingyenesen elérhető 5.-es és 6.-os elektronikus tankönyvek tartalmát is az érintett témában, amelyekben az alábbiakat találtam.

5. osztályban a természettudomány tankönyv tartalma: 
1. Sejtek, szervek, szervrendszerek

2. Mozogj az egészségedért!

3. A táplálkozás hatása a szervezetre

4. A légzés - a környezet hatása az emberi szervezetre

5. A vérkeringés és a kiválasztás

6. Az érzékelés

7. Szaporodás

8. Betegség, fertőzés, járvány

6. osztályban a természettudomány tankönyv tartalma:

1. Sejtek, szervek, szervrendszerek

2. A mozgás

3. A táplálkozás

4. Az egészséges táplálkozás I.

5. Az egészséges táplálkozás II.

6. A légzés és kiválasztás

7. A vérkeringés

8. Az érzékelés

9. A bőr

10. A szaporodás

11. Az ember egyedfejlődése

12. Betegség, fertőzés, járvány

Összefoglalva elmondható, hogy a NAT tartalmazza a megfelelő információt ahhoz, hogy a diákok elérjenek egy egészséges és fitt felnőttkorba.

Mégis, hogyan lehetséges az, hogy nem ezt tapasztaljuk általánosan? Hogyan lehetséges az, hogy szív- és érrendszeri problémával, cukorbetegséggel, túlsúllyal és depresszióval küzd a felnőtt lakosság nagy százaléka? Miért fáj a háta, a dereka, a térde, a feje?

A tananyagban tehát a szükséges információ megtalálható ahhoz, hogy a leírt cél elérhető legyen a gyerekek számára. Tehát ebben nincs hiba. Következésképpen a módszer lehet az, ami változtatásra szorul, vagyis az információátadás formáját kell újragondolni. 


\section{A járványhelyzet okozta online oktatás lehetőségei}

2020. március 16-án a kontakt oktatást online formára változtatta a kormány a kialakult pandémiahelyzet miatt. Ez egy újabb inspirációt és egyben jó lehetőséget jelentett, hogy vizsgáljam, hogyan lehetséges felkészíteni egy diákot az egészséges felnőttkorra úgy, hogy alapvetően a tananyag megfelelő, de a tananyag átadás módszerén változtatnom kell, mert a korábban megszokott kontakt formát felváltotta az online oktatás.

Egyedül a diák egy szobában, kezében egy telefonnal, tablettel, laptoppal vagy PC-vel - a testnevelő tanár egy másik lakásban, másik szobában, szintén kezében egy IKT-eszközzel.

Az új helyzetben több újfajta módszert kipróbáltam, jelen kutatásban ezek közül a következő kettő módszerre összpontosítok:

- Előre elkészített videofelvételek gyakorlatsorokról, amelyeket linken keresztül osztok meg a tanulókkal, ezek alapján különböző edzésmódszerekkel tudtak edzeni.

- Mobilapplikációval támogatott oktatás.

A gyakorlati tapasztalatok alapján az alábbiakban fogalmazhatók meg az előnyök, a hátrányok és egy későbbi cél.

\section{Elönyök:}

- többször felhasználható anyagok;

- tanár nélkül, önállóan elvégezhető;

- a rögzített információt "bármikor" elvégezheti.

\section{Hátrányok:}

- nem látom a diákot a feladat elvégzése közben;

- nem ellenőrizhető, hogy elvégezte-e, ha igen, hogyan;

- nem tudom javítani, ha nem a helyes mozdulatsort végzi;

- nem közvetlenül ott és akkor tudom átadni az elvégzendő feladatot;

- nem megfelelő a terhelés, nincsenek szintek;

- nincs közvetlen visszajelzési lehetőségük a diákoknak.

Cél:

Olyan applikáció létrehozása, amely:

- magyar nyelvü; 
- a diákok ki tudják választani maguknak a megfelelő szintet, (gyakorlati tesztfeladatok végrehajtása alapján a program besorolja);

- a szintlépéseket jutalmazza virtuális, egészséges táplálékkal (pl. egy grapefruittal) és ösztönzi a gyerekeket arra, hogy minél több jutalmat gyújtsenek össze, ez alapján tud jó jegyet szerezni, és/vagy magasabb szintre jutni;

- képes érzékelni az eszköz, a feladat végrehajtásának a módját:

- a mozgás gyorsaságát,

- a gyermek pulzusát (pulzuskontroll),

- a végrehajtott feladat mennyiségi egységeit.

\section{Összegzés}

A villámsebességgel történő online oktatásra való áttérés új módszerek kialakítását tette szükségszerúvé a tanárok számára. Az újonnan kialakult oktatási helyzetben a legfontosabb feladata a tanároknak a diákokkal való folyamatos kapcsolattartás és a gyerekek motiválása arra, hogy napi rendszerességgel végezzenek valamilyen testmozgást.

Felvetődik bennem néhány fontos kérdés: A testnevelés és egészség tanítás hol kezdődik? Az iskolában, vagy otthon?

Ha nem történik meg a családban az egészséges életmód szokásrendszerének kialakítása, akkor az iskola mit tehet ezért?

Úgy gondolom, hogy a diákoknál lévő IKT-eszközökkel jól motiválhatjuk őket mi testnevelők a helyes táplálkozásra és a rendszeres mozgásra, például mobilapplikációk segítségével, hiszen az okostelefonok és okosórák folyamatosan a diákoknál vannak, használják is azokat. A feladatunk az, hogy tanítsuk meg jól használni azokat, találjunk vagy készítsünk számukra jó mobilapplikációkat.

Célom olyan eszközök felderítése, később megtervezése, amelyek motiválóan hatnak a diákok egészséges életmódbeli szokásrendszerének kialakítására, s amelyek önálló mozgásos munkavégzést biztosítanak számukra, olyan eszközöket, amelyek segítenek a diákoknak a tanulás, a gyakorlás, az ellenőrzés és az értékelés folyamatában egyaránt. 


\section{Irodalomjegyzék}

Kvaszingerné Prantner Csilla (2018): Overview of the accessibility of webpages, related research, advantages, guidelines and recommendation. In: Teaching Mathematics and Computer Science, 16: 2 pp 233-262., 30 p.

\section{https://doi.org/10.5485/TMCS.2018.0452}

Lengyelné, Molnár Tünde: Hallgatói kérdőív elemzése. - In: Kis-Tóth, Lajos (szerk.) Elektronikus tanulási környezetek kialakítása I., Eger, Magyarország : Líceum Kiadó, (2009) pp. 52-63.

Lengyelné Molnár Tünde (2014): Kutatástervezés - Eger: Líceum Kiadó

Nagy Zsuzsa, Müller Anetta, Simon Ugron Ágnes, Zidek Péter, András Álmos (2016). A testnevelésórán alkalmazott pulzusmérés szerepe a tanulók differenciált oktatásában. [online] [2020. 08. 24.] http://publikacio.uni-eszterhazy.hu/1516/1/161-177 Nagy.pdf

Racsko, Réka ; Kis-Tóth, Lajos (2019): A technológia szerepe a 21. századi tanári kompetenciájának fejlesztésében. Katolikus Pedagógia: katolikus Pedagógiai Tanszéki Folyóirat / Nemzetközi Neveléstudományi Szakfolyóirat 8 : 1-2 pp. 49-65. , 17 p. (2019)

Révész László (2019). A testnevelés tanításának néhány kérdése. [online] [2020. 08. 24.] <DOI: 10.15773/EKE.HABIL.2019.002>

Varga, Attila (2018). IKT-eszköz-használati szokások vizsgálata testnevelés szakos hallgatók körében. Az Eszterházy Károly Egyetem tudományos közleményei (45. köt.). Tanulmányok a sporttudomány köréből = Acta Universitatis de Carolo Eszterházy Nominatae. Sectio Sport. pp. 17-24. ISSN 2677-0105 [online] [2020. 08. 24.] http://publikacio.uni-eszterhazy.hu/4641/1/Varga 17 24.pdf 